\title{
КОМАНДЫ ГЛАВ МАЛЫХ РОССИЙСКИХ ГОРОДОВ: ВЕКТОРЫ ПЕРЕМЕН
}

\author{
A.E. Чирикова
}

\author{
(chirikova_a@mail.ru) \\ Института социологии \\ ФНИСЦ Российской академии наук \\ Москва, Россия
}

Цитирование: Чирикова А.Е. Команды глав малых российских городов: векторы перемен // Власть и элиты. 2020. Т. 8, № 2. С. 72-112.

DOI: https://doi.org/10.31119/pe.2021.8.2.4

Аннотация. На основе материалов эмпирических исследований оценивается уровень профессионализма команд глав пяти малых городов в трех российских регионах. Кейсы существенно различаются между собой, но большинство из них (4 из 5) представляют собой города со сложным социально-экономическим положением, которое за последние годы заметно ухудшилось.

Интервью, проведенные с ключевыми фигурами городской политики, бизнеса и экспертами, позволили описать конкретные практики принятия решений в команде. Учитьвались оценки как самих членов командь, так и лидеров исполнительной власти, а также мнения тии, имеющих опыт взаимодействия с командой и ее лидерами. Проведенное исследование показало, что практики распределения власти в городских командах, несмотря на всю их схожесть, не являются унифицированными. Авторитарные формы взаимодействия с командой со сторонь городских лидеров остаются доминирующими. Готовность команд к работе по модели «солидерства» остается достаточно низкой. Однако не исключено, что при улучшении социально-экономической ситуации и адекватном отборе кандидатур на пост глав городов, ситуация может измениться.

Ключевые слова: малый город, глава города, команда главы города, лидерство, модель солидерства, эббективность работы команды. 


\section{ВВЕДЕНИЕ: КОМАНДЫ СТАНОВЯТСЯ ВАЖНЕЕ ИХ ЛИДЕРОВ. ТАК ЛИ ЭТО?}

К теме команд глав малых городов в своих эмпирических исследованиях мы обращались не раз и в разных контекстах (см., например: [Лапина, Чирикова 2002; Чирикова, Сельцер 2014; Чирикова, Ледяев 2017]). Основная тема, которая была в центре проводимых эмпирических исследований в разные годы - полицентризм/моноцентризм во властных отношениях, характерных для регионального и муниципального уровней.

В настоящей работе мы вновь хотели бы оценить значение команды для уровня муниципального управления. Чем обусловлен обострившийся интерес к этой теме в начале $2000-х$ годов и в последующие годы?

В докладе «Эволюция управленческого лидерства», подготовленном входящим в структуру Andersen Consulting Институтом стратегических изменений по результатам специального исследования, проведенного в конце 1990-х годов, рассматривался вопрос об изменении характера лидерства в связи с новыми задачами, стоящими перед компаниями. Целью исследования было выявить, какой профиль лидера станет определяющим в будущем с точки зрения 20 крупнейших западных теоретиков и методологов менеджмента, с одной стороны, и 100 лидеров бизнеса из Нью-Йорка, Сан-Франциско, Лондона, Мельбурна и других городов, представлявших 88 наиболее динамично развивающихся компаний США, Европы, Австралии, - с другой. Привлеченных к исследованию респондентов попросили проранжировать такие качества лидера, как глобальное мышление, способность предвидеть новые возможности, умение работать с командой и партнерами, и оценить место этих качеств в бизнесе в прошлом (5-10 лет назад), настоящем и будущем (5-10 лет вперед). Всего для оценки было предложено 14 характеристик глобального лидерства.

По данным исследования, большинство респондентов склонялось к точке зрения, что XXI в. потребует модели, построенной на принципе командного, а не единоличного лидерства [Чирикова 2002]. Речь шла о необходимости постепенного отказа от авторитарной модели лидерства и замены ее моделью «солидерства», которая предполагает сознательный отказ командного лидера от части своей власти и полномочий и передаче их членам своей команды. 
Сегодня и в будущем, по мнению как российских, так и западных исследователей [Виханский, Миракян 2018; Филонович 2003; 2007; Управление персоналом 2002; Белибин 2003; 2007] лидер команды в большей степени должен стремиться к более мягкому влиянию, основанному на способности интегрировать общекомандные интересы, и убедительно транслировать их другим, используя для этого широкий спектр технологий коммуникаций. Это потребует от новых лидеров большого внутреннего динамизма и восприимчивости с учетом разнородности этнических и возрастных культур, представленных в организациях, а также личного мастерства, стремления к самосовершенствованию, высокого уровня самокритичности, технологической компетентности, приведет к необходимости смены принципов работы с командами как в бизнесе, так и на государственной и муниципальной службе.

Прошедшие с начала 2000-х годы показали: команды вместе с их лидерами являются главными акторами перемен, и их участие в управлении организациями не стоит недооценивать, отдавая все победы в управлении только их лидерам. Подход, согласно которому команда разделяет лидерство со своим руководителем, некоторые называют «золотым правилом» менеджмента [Маслюкова 2005].

Одним из первых в 1990-х годах на ведущую роль команды указал Рэймонд Меридин Белбин, создав теорию командных ролей [Белбин 2003; 2007]. Если раньше, по его мнению, теория управления понималась исключительно с позиции иерархии (во главе стоял лидер, который давал поручения членам команды, а те распределяли задания подчиненным), то со временем такая модель стала неэффективной. Главное, по его мнению, правильно определить роль каждого члена команды, создав работающие горизонтальные связи.

В России последователем теории командных ролей является Тахир Базаров, однако он рассматривает не столько роли членов команд, сколько необходимость множественности ролей самого руководителя команды [Управление персоналом 2002; Базаров, Рыбкин, Пыркова 2009].

Такая модель многими рассматривается как упрощение или отечественная альтернатива модели Марджерисона-Маккенна [Жуков, Журавлев, Павлова 2008]. Однако все же нельзя не признать, что она позволяет более системно подойти к деятельности лидера любой команды, выделив в его деятельности разные, но необходимые управленческие функции. 
Несмотря на многочисленные исследования командообразования в бизнес-организациях, все же нельзя утверждать, что в системе государственной и муниципальной службы в России эти темы проработаны достаточно хорошо. Тем не менее, в России, особенно в последнее время тезис о необходимости командного лидерства разделяется многими российскими специалистами в области управления государственной службы [Корниенко 2000; Долгов 2016; 2018; Шебураков 2017].

Так, последовательный исследователь команд государственной службы Михаил Долгов замечает: «Вопросы формирования и развития управленческих команд на всех уровнях государственной службы являются фундаментальной задачей для развития культуры современного управления и проведения качественных изменений. Одной из актуальнейших задач текущего периода является необходимость перехода к командному лидерству на всех уровнях государственной службы. Отсюда - необходимость развития управленческих команд и формирования культуры командного лидерства» [Долгов 2018: 365].

Данная цель, сформулированная исследователями государственной и муниципальной власти, была не только озвучена в научных публикациях, но и нашла свою реализацию в программе подготовке управленческих кадров для российских городов, поддержанную научными и банковскими структурами России в 2020 г.

Разработанная программа подготовки управленческих кадров для 100 крупнейших городов России подготовлена в соответствии с международным стандартом MPA (Master of Public Administration) Сколково, Банком ВТБ и Высшей школой управления. Стартовала она в июле 2020 г. Основная цель программы - сформировать в городах команды управленцев, обладающих передовыми практиками и знаниями в сфере городского менеджмента. Программа призвана создать условия для запуска в России проектов ускоренного развития экономики городов, создания комфортной среды для жизни людей и вывода российских городов на лидирующие позиции в международных рейтингах по качеству жизни ${ }^{1}$.

${ }^{1}$ В состав команд включены мэр (лидер команды), его заместители по ключевым направлениям, заместители губернатора. В рамках программы участникам предстоит работа над проектами трансформации города, а также поиск релевантных технологических и управленческих решений. Задача - чтобы участники вышли не просто с пониманием передового российского и между- 
Разделяя позицию о необходимости реализации подобных программ для повышения эффективности управления, мы все же убеждены, что такая серьезная работа не может быть проделана продуктивно без эмпирического изучения процессов, происходящих в функционирующих командах государственной и муниципальной службы.

В данной работе мы хотели бы рассмотреть некоторые важные аспекты командной работы на примере малых российских городов, опираясь на эмпирические исследования, проведенные нами в разные годы (20112020) совместно с Валерием Ледяевым и Дмитрием Сельцером. Всего исследованием было охвачено пять городов из трех российских регионов (Ивановская, Тамбовская области и Пермский край). Проведено 101 интервью с представителями локальной элиты, в которую вошли главы городов, председатели городских советов, депутаты, представители бизнеса, директора, руководители местных партий, руководители СМИ, эксперты. Исследование носило более широкий характер, но проблемы работы команд и их формирование занимали в нем ключевое место. В четырех городах исследование проводилось в два этапа. На первом этапе фиксировалось состояние команды, ее состав, характер взаимодействия с главой (мэром). При анализе полученных результатов первого этапа, с одной стороны, особое внимание уделялось моделям власти (моноцентричной, полицентричной) и их связи с эффективностью командной работы, с другой - оценивался уровень зависимости/независимости команды от своего лидера - главы города [Чирикова, Сельцер 2014].

Исследование позволило описать конкретные практики принятия решений в команде с помощью оценок, полученных как от самих членов команды, так и от лидера исполнительной власти. Оценки дополнялись мнениями внешних лиц, имеющих опыт взаимодействия с командой и ее лидером, а также экспертным мнением.

Проведенное исследование позволило убедиться в том, что практики распределения власти в городских командах, несмотря на всю их схожесть, не являются унифицированными, однако авторитарные формы взаимодействия с командой со стороны лидера остаются доминирующими. Эффективность работы таких команд трудно поддается экспертизе, поэтому однозначные оценки дать сложно.

народного опыта в области управления городами, а с готовой программой развития своего города и могли применить полученные навыки для ее реализации [Стартовала программа 2020]. 
На втором этапе исследования мы были ориентированы на более углубленное изучение командных процессов. Теперь важно было не только понять используемые модели власти при управлении команды, но и выявить закономерности формирования команды, ее способность работать по модели «солидерства».

Не менее значимым было стремление определить готовность лидера команды работать с людьми, которые вместе с ним пришли во власть, или с членами команды, оставшимися от старого главы. Нас также интересовал вопрос о том, как менялись команды в одном и том же городе.

Проведение второго этапа исследования через несколько лет в одном и том же городе позволяло анализировать произошедшие изменения, опираясь на тонкие, иногда невидимые процессы, происходящие в команде, в уже знакомой для нас среде. И наконец, еще один вопрос, на который нам хотелось бы найти ответ: могут ли у слабого главы быть сильные команды или, наоборот, могут ли у сильного главы быть слабые команды? Ответы на поставленные вопросы нам были необходимы для оценки того, способна ли власть в малых российских городах работать по модели «солидерства», которая предполагает разделение лидерства между руководителем и членами команды, в противовес единоличного лидерства в командной работе.

\section{КОМАНДЫ МАЛЫХ РОССИЙСКИХ ГОРОДОВ ВО ВРЕМЕННОЙ ПРОЕКЦИИ: ЭМПИРИЧЕСКИЙ АНАЛИЗ}

В предлагаемой работе будут проанализированы пять кейсов малых российских городов. Это очень различающиеся между собой случаи, которых объединяет одно, большинство из них (4 из 5) представляют собой города со сложным социально-экономическим положением, которое за последние годы заметно ухудшается. В этом случае команды малых городов и их лидер неизбежно должны искать управленческие инструменты, позволяющие смягчить кризисную ситуацию. Условия пандемии еще более усложняют управленческие задачи и превращают командное лидерство не просто в желаемую или нежелаемую форму построения командной работы, а возможно в единственно эффективную форму управления городом в условиях кризиса на фоне пандемии. 


\section{Город X: слабая команда при слабом главе: можно ли изменить ситуацию?}

Пример города $\mathrm{X}$, рассмотренный во временной перспективе, позволяет утверждать: слабый глава, как правило, формирует слабую команду. Даже в том случае, если от предыдущего главы ему в наследство достается вполне работающая команда. Это особенно заметно на примере города $\mathrm{X}$, в котором исследование местной власти проводилось в два этапа: первый был реализован в 2011 г., второй проходил в 2019 г.

Данный кейс - отличная демонстрация того, что у слабого главы не может быть сильной команды.

На момент проведения первого этапа исследования состояние команды города Х было вполне удовлетворительным, и она четко выполняла свои задача. Проблемы начались чуть более года спустя, когда тогдашний сильный глава города, переизбравшийся на второй срок, перестал доверять своей команде и даже начал конфликтовать с ней. В результате из команды ушли две ключевые фигуры, на усилиях которых во многом строилась работа главы, - первый заместитель главы города и заместитель главы по социальной политике. Это резко подорвало эффективность работы команды, и если бы глава в скором времени не ушел на повышение в край, то неясно было бы, чем это могло закончиться.

Тем не менее члены команды тогдашнего главы были убеждены: даже потерявшая двух ключевых фигур команда того времени была сильнее, нежели команда сегодняшнего главы, если бы он ее не бросил, а дал бы ей расти: Могу сказать, когда глава уходил в край, у нас была команда. Мы не предполагали, что он уйдет. Я пришла за год до его ухода. Я пошла на зама по правовым вопросам. Я пришла в новую команду. И в приниипе мы все сработались, у нас команда была. Но глава нас бросил. Мы были огорчены, что мы его потеряли, - вспоминает тот период сегодняшняя глава аппарата и заместитель главы по правовым вопросам.

После повышения прежнего главы через некоторое время (первые полтора года это место заняла женщина, которая быстро ушла) пришел новый глава, ставленник рассорившегося с командой предшественника. Он оказался полностью зависимым от ушедшего на повышение человека, который, несмотря на свою работу в крае, претендовал на полную власть в городе. Именно он на момент проведения второго этапа ис- 
следования диктовал заменившему его главе правила работы в команде. Это привело к тому, что команда к началу второго этапа исследования практически распалась.

Новый глава - ставленник серого кардинала, понимал, что его команда требует усиления и принял на работу первого заместителя из бизнеса, чтобы усилить команду, но новый человек смог проработать на своей должности не более двух месяцев, так как глава был снят со своей должности по приказу губернатора за нарушение режима поведения в условиях пандемии. Бывший первый заместитель стал руководителем аппарата у нового и.о. главы, который был назначен вместо снятого слабого главы.

Второй этап исследования проводился накануне отставки главы, поэтому полученные оценки отражали в полной мере высокий уровень недовольства в отношении команды и самого главы. Им были недовольны практически все - и жители города, и представители элитных групп, поэтому его отставка выглядела вполне ожидаемой и в полной мере оправданной.

Наиболее частый ответ на вопрос, какая у главы команда, звучал так: Он одиночка, находится под влиянием, и у него нет команды.

Частично сложившееся положение дел было обусловлено дефицитом кадров, но еще в большей степени причиной слабой команды стало неумение главы бороться за кадровый ресурс: Я понимаю, какой дефиичит у нас хороших кадров. Я просто обескуражена глупостью главы... Я обескуражена тем, что он мне позволяет покинуть администраиию без всякого диалога со мной. Не держатся ни он, ни глава аппарата за кадры, - поясняет пресс-секретарь главы, которая намерена в ближайшее время уйти из администрации.

Важно, что он был не только не способен привлекать людей в команду, но и неуважительно относился к тем, кто находился внутри команды и на нижних, и на верхних этажах властной иерархии: У него команды вообще нет... Они даже друг с другом не могут договориться. Это не мое, и это тоже не мое, так глава разбирался с бывшим первым заместителем. Девчонки срочно готовят проект. Сидят ночами. Приходят к главе, я передумал, не будем проект сдавать... А почему Вы нам не сказали? Молчание в ответ. Он так к коллективу относится, не замечая усилий других, - восклицает депутат городской думы.

Тезис о непоследовательности и хаотичности главы в отношениях с командой подтверждает и пресс-секретарь главы, которая намерена 
в ближайшее время команду покинуть: Мне не с чем сравнивать, но я не могу не сказать о хаотичности и импульсивности главы при работе с командой. Хочется работать в здоровой команде, которая знает, куда идет. Мне некомфортно жить в условиях хаоса. У меня нет ошущения, что то, что я делаю, понято и принято этой командой.

Глава аппарата подтверждает факт отсутствия команды у главы города: Говорить о команде пока сложно. Команда - это сработавшийся, сплоченный коллектив. Коллектив, объединенный общими иелями. У нас пока такого нет. Последние пять лет город трясет. Команда так и не сбормировалась.

Сам глава признается, что ситуация с командой сложная и разобраться с тем, почему это именно так, ему не всегда удается: Когда глава приходит, он присматривается. Были моменты, когда мы с кемто расставались. Прошло уже два года, и честно скажу, я сам многого не понимаю на сегодняшний день. Команды у меня нет.

Почему сегодня не получается сформировать команду, разъясняет предприниматель, депутат городской думы: При прежнем главе при всех его недостатках была четко выстроена иерархия. Может быть, благодаря усилиям административного персонала. Прежде всего, благодаря усилиям первого заместителя, который был развернут на общение. С помощью команды творческий потенциал главы раскрывался. Сейчас у нынешнего главы этого нет. Он не иенит людей, на него работающих.

С годами ситуация ухудшилась. Место первого заместителя занял совсем не сильный управленец: Пришел действующий глава, и назначил на должность первого зама ограниченного человека. Он не состоялся как первый зам. Хотя он два года замещал эту должность. Он не организатор и не лидер. Хороший парень, добрый... Говорливый... Эта должность много лет была пустой. Мы по частям растаскивали эти обязанности. И работали, как могли. В полную силу мы не работали.

Как бы в подтверждение сказанного главный редактор газеты замечает: У главы очень плохие отночения с первым заместителем. Разве это команда? Каждый раз, кажется, что заместитель главы работает в администрации последний день. От и до, и не слова больше. И никакой инициативы. Ни шага никуда не сделает.

Об ограниченном функционале первого заместителя напоминает и бывший мэр города, сегодня начальник управления внутренней политики в районе: Первый зам - он целиком погружен в хозяйство, там 
трубу надо отремонтировать. Здесь гвоздь забить. На большее он просто не способен.

По мнению представителей элитного корпуса, дело не только в распределении фигур в команде, которые оказались не всегда на своих местах, но и в неправильно организованной работе внутри команды. В этом случае большая часть власти делегируется одному из ее членов, который имеет высокие компетенции, фактически перетягивая власть на себя.

Глава аппарата и одновременно заместитель по правовым вопросам, в руках которого сконцентрировано много публичной власти, по мнению элитного корпуса, нередко перетягивает власть на себя: Руководитель аппарата обладает большой властью. Она управляет внутренней политикой. Все в ее руках. Она командует всем парадом. Являясь юристом, она составляет юридичекие акты, выстраивает отношения с городской думой, как с представительным органом, с общественными формированиями. Вся информационная политика в ее руках. И она руководит всем процессом, - уверен бывший мэр.

По оценкам другого информанта, фигура руководителя аппарата хотя и весьма неоднозначна, но она владеет ситуацией в городе: Она в команде только потому, что работа ее устраивает... Они каким-то образом выстраивают отношения между собой, но я бы не назвал их одной командой.

Но руководитель аппарата допускает ошибки, хорошо заметные представителям элитных групп, хотя многие из них признают - дело не только в ней одной: Руководитель аппарата все равно многое упускает... Она хороший специалист. Но я не знаю, как она работает в командной иерархии. Она может продавливать достаточно глубоко нужные решения. Однако мы видим митинги на соборной площзади. Значит, повод был дан, значит, вовремя не среагировала, - считает депутат городской думы.

Сама глава аппарата и заместитель главы по правовым вопросам признает, команда не сформирована. Причина не в слабости главы, а в кадровом дефиците. Пришедший на место первого заместителя человек, вполне может усилить команду со временем: Кадровый дефииит в органах власти присутствует уже очень давно. На всех уровнях. Адекватного руководителя - надо выращивать. Выращиваются спеицилисты с первой категории. Сегодня я не могу сказать, есть ли у нас команда. У нас буквально месяи, назад сменился первый зам. Говорить 
о полной команде я пока не могу. Первый зам только начинает вникать в дела. Он пришел со стороны, из коммерческих структур. Ему надо вникнуть в вопросы местного значения.

Объясняя причины, по которым человек из коммерческой структуры был назначен первым замом, она объясняет это следующим образом: «Почему человек из бизнеса? Дума проработала в новом составе, и он в этом составе обозначился. Он оказался лидером, который может формировать определенную позищию представительного органа. И получать большинство по каким-то решениям. Он себя в этом отношении проявил. Я надеюсь, что у того, кто его продвинул, он не висит на крючке. И тогда он сможет реализовать себя как первый зам. От его работы команда может выиграть.

Свою версию назначения нового первого заместителя имеет и глава города, который убежден в том, что вновь назначенный управленец располагает для осуществления этой деятельности необходимыми качествами: У него хороший возраст. У него хорошее образование. Он прошел школу бизнеса. И он ее перерос. Он стал депутатом. Это человек, который вникает в каждую проблему... Он видит людей. Когда долго сидишь, замыливается глаз. Если ты не видишь людей, ничего не получится. Он умеет считать деньги. Он меня разгрузит. В опредетенной части. Главе надо заниматься другим делом.

Некоторая часть элитного корпуса связывает назначение первого зама с дальнейшими позитивными изменениями в городской власти: У меня с вновь назначенным первым замом связаны большие надежды... Он в лучшем смысле этого слова - амбициозный. Он думающции и мотивированный. Он хочет чего-то добиться, - замечает в своем интервью депутат городской думы.

Другой информант в этом не уверена, хотя и признает - человек он грамотный: Сейчас он замом сделал человека из бизнеса. Грамотный человек. Но у него в голове прежде всего деньги... Нельзя руководителю города рассуждать категориями только денег. Если он не перестроится, то это в конечном счете будет плохо», - убеждена бывшая глава города, сегодня депутат городской думы.

Пресс-секретарь действующего главы также не уверена, что первый заместитель наведет порядок в администрации, преследуя исключительно интересы города, а не свои собственные: У него точно есть свои конкретные задачи и конкретные интересы. Мне стало особенно некомфортно, когда я увидела методы его работы, которые никак 
не соотносятся с моим миром, и с желанием сделать для города что-то xоромеe.

Глава аппарата пока не уверена, получится ли у нее работа с первым замом, но предпочитает надеяться на лучшее: $Я$ не могу сказать, смогу ли я повлиять на его выьор новых людей в команду. Мь с ним пока недостаточно работаем. Будет ли у нас с ним консенсус, взаимопонимание, я сказать не могу. Хотя людям я стараюсь доверять. Это тем же возврашается. Доверием. Будет ли он менять команду, окружение, я надеюсь, что будет... Есть кого сменить.

Некоторые из информантов связывают приход первого зама как сигнал будущей смены действующего главы, но пока не знают, приведет ли это к заметному улучшению ситуации в городе: Первый заместитель сядет на место главы через некоторое время, они уже начали процесс подготовки по передаче ему функиий. Он присутствует на многих мероприятиях. Глава буквально живет у него в кабинете. Они постоянно находятся в кабинете друг друга, - рассказывает руководитель местного телевидения.

Итак, результаты второго этапа исследования убедительно показывают, за прошедшие годы были разрушены оставшиеся после ухода главы в край остатки команды, которые на фоне нынешней команды воспринимаются как вполне удовлетворительные. Сложившееся сегодня положение дел в команде можно назвать катастрофическим. Это в той или иной степени признают как сами члены команды, так и люди, наблюдающие за ее работой со стороны.

Смена первого заместителя главы хотя и породила некоторые позитивные ожидания, но совсем ненадолго. Приход бизнесмена во власть оценивался неоднозначно и с большими опасениями, что теневые практики будут оставаться доминирующими и это не приведет к улучшению ситуацию. Насколько оправданы такие ожидания, на момент проведения второго этапа исследования было неясно. Но вывод о том, что нынешний глава должен был покинуть свой пост, как не справившийся со своей работой был очевидным. Так фактически и произошло. Через два месяца власть в городе переменилась, на место слабого главы пришел бывший глава района, сильный управленец, возглавлявший район около десяти лет. Он сразу же приступил к постепенному изменению команды, переместив первого заместителя на место главы аппарата, задачей которого было не просто улучшение ситуацию в городе, но и слияние двух уровней власти в краткосрочной перспективе. 
Данный кейс убедительно показывает: если глава слаб, то он слаб во всем. У него не получается работа с командой, в результате сами представители команды считают свою работу неэффективной, как и представители городской элиты. И это объяснимо. Слабый и ведомый глава не умеет выстраивать отношения с локальной элитой, наконец, он не пользуется авторитетом у региональной власти. Как следствие слабая мотивация командной работы и постоянные переназначения, которые не дают должного результата. В известном смысле лидер в команде не заменим, даже если команда сильна. Если команда слаба, то этот вывод оправдан вдвойне.

Не исключено, что новый сильный глава сделает соответствующие перестановки в команде, усилит контроль, найдет новые рычаги для мотивации сотрудников. Это будет способствовать тому, что даже те, кто останется в команде от прежнего главы, будут работать эффективно и слажено.

Приведенный пример убедительно показывает: при слабом главе надеяться на реализацию модели «солидерства» команды вряд ли оправданно. Единственным инструментом для изменения сложившейся ситуации является смена главы, что и было в результате сделано.

Кейс дает основание для важного вывода: переход к модели «солидерства», где команде делегируется ключевая роль, не может быть совершен автоматически. Это может произойти в том случае, если глава силен, а состав команды подобран не по критериям лояльности, а по уровню компетенций.

\section{Город Y: перемены в команде очевидны, но не закончены...}

На первом этапе исследования в городе Y существовало два уровня власти - городская и районная. Две команды помогали управлять своим главам. Однако структура власти и профиль двух команд существенно отличались друг от друга.

Городская команда, по мнению большинства респондентов, отличалась вполне традиционными отношениями: они строились на принципах полного подчинения главе, которые сложились в течение длительного времени и которые никто из членов команды не был способен изменить. В такой ситуации глава полностью контролировал происходящее в команде, держал все имеющиеся ресурсы в своих руках, при этом всем остальным членам команды не оставалось ничего другого, как подчиниться. Ситуацию с командой главы города наиболее 
емко описал известный в городе журналист: Если чиновники главы города начнут играть свою игру, то глава их сразу уволит.

Не располагал властными ресурсами даже сити-менеджер города, который вынужден был всецело подчиняться главе, который возглавлял на момент исследования представительную, а не исполнительную власть.

Тем не менее, по мнению городских элит, нельзя было исключать, что у членов команды оставались некоторые ресурсы для «собственного маневра» вполне традиционного характера. Чаще всего эта «игра» заключалась в протекции тем или иным заинтересованным лицам, например в торможении каких-то невыгодных для них организационных новаций.

Сам тогдашний глава города, по мнению информантов, совершил много ошибок в работе с командой, основные из которых - либо слишком высокое доверие к членам команды, либо наличие скрытых бизнесинтересов, которые команда должна была обслуживать: Это бълло ошибкой прежнего главы. Когда ему говорили, убирай финансистку, она заворовалась, он не слушал... Он этого или просто не замечал, потому что у него глаз замылился, или не хотел, чтобы это влияло на его бизнес-дела, - вспоминает то время известный в городе предприниматель, депутат городской думы.

Совершенно иной характер взаимоотношений сложился в районной администрации. Там не только не было явного доминирования главы администрации района, но фактически все бразды правления в целом ряде направлений деятельности администрации захватили два его заместителя.

Наши респонденты по-разному объясняют причины такого «перемещения власти». Одни убеждены в том, что имела место «отдача выборных долгов»: без помощи своих заместителей глава администрации района не смог бы сохранить свой пост. Другие настаивали на том, что передача реальной власти заместителям - это не долг, а скорее их более высокие, чем у главы администрации, персональные ресурсы. $И$ mom, и другой действительно сегодня являются основными движущими силами в команде, - убежден эксперт.

Ум, профессионализм, энергия, готовность рисковать - эти качества, по мнению респондентов, и определяли реальное лидерство в команде двух заместителей главы района.

Складывание такой не вполне стандартной ситуации было обусловлено правильно (с точки зрения доминирования) выстроенными от- 
ношениями с главой района его заместителями, умением им манипулировать. Не менее важно то, что утрата лидерства руководителем районной администрации была связана с очевидными недостатками и слабостями самого руководителя. Некоторые из респондентов говорили о том, что главе района нравится быть богом с закрытыми глазами.

Следствием «звездной позиции», не оправданной реальностью, явилось отсутствие доверия в команде, повлекшее за собой неумение работать «с маленькими людьми», которых он не знал и не хотел знать, хотя они на него пахали шесть лет.

Тем не менее, избранный сегодня депутат, предприниматель, ранее работавший в команде главы района, характеризует ее как достаточно эффективную: Команда у районного главы была хорошая. Нынешний глава из этой команды лучших забрал, а худиих оставил за бортом.

Таким образом, сложившиеся паттерны распределения власти в командах города и района в те годы убедительно показывали, что уровень влияния в команде высокопоставленных руководителей и других членов команды, во многом зависели от психологического профиля главы, его готовностью делиться властью с другими членами команды, с их профессиональными качествами. Однако готовность делиться властью могла быть реализована только при наличии в команде профессионалов, способных поддержать главу и защитить от непредвиденных обстоятельств, а не воспользоваться его доверием. Важный вывод, который был сделан на первом этапе исследования - чем сильнее члены команды, тем более сложным становится распределение власти внутри нее. И далеко не все главы способны с этим справляться.

Второй этап исследования, проведенный через восемь лет, показал, что во власти города и района произошли существенные персональные перемены, которые затронули в том числе их команды.

Прежде всего, за счет слияния уровней власти глава района перестал быть действующей фигурой. В то время как новый глава городского округа (2019 г.), избранный в 2013 г. сначала главой городского поселения, а в 2016 г. главой муниципального района, получил все властные полномочия, возглавив новую слитую территорию. Естественно, что в этом случае он стоял перед необходимостью обновлять свою команду с учетом того, что теперь его выбор команды должен был соответствовать тем масштабным задачам, которые необходимо было реализовать.

Пока процесс формирования команды у главы слитной территории не закончен. Сказывается нехватка квалифицированных кадров, из- 
вестная привязанность главы к членам своей команды, особенно к топам, что делает процесс становления команды не столь быстрым. Тем не менее, информанты признают: команда у главы есть. Некоторые называют ее хорошей. Другие признают: над формированием команды главе следует работать дальше.

Среди тех, кто готов назвать команду главы городского округа хорошей, заметен министр территориального развития края, который убежден: Глава городского округа относится к числу людей, которые заставляют всех работать на себя. Он молодеи, в этом плане. Сам он не стоит в стороне. Есть ряд проектов по благоустройству, это чисто его проекты. У него очень хорошая команда в администрации. Там такая сборная солянка. Я их хорошо знаю. Он собрал их из поселений. Это сливки, и за счет этого сегодня город Ү чуть впереди.

Высоко оценивает потенциал команды и наш эксперт, признавая, что общая экономическая ситуация в городе далеко не простая: Глава молодеи, в том, что он создал хорошую команду. И она на него работает. Регионалы связывают с ним будущее объединенной территории. Но мне кажется, что ситуачия в городе является отражением экономической ситуации. В городе, мягко говоря, невесело. Если раньше город мог опереться на металлургический завод, то теперь это не так.

Расценивает свою команду как весьма неплохую и заместитель главы городского округа по социальным вопросам. Основанием для подобной оценки служат многочисленные гранты, которые команде удается выигрывать на федеральном и региональном уровне: Мне кажется, что команда у нас неплохая. В прошлом году на культуру мы получили 25 млн за счет участия в грантах и конкурсах. У нас каждый понедельник офис заседает. Глава воспринимает наши победы как должное. Он недавно сказал: я до такой степени привык, что информаиця о победах для меня стала обыденностью.

Солидарен с высказанной оценкой и бывший председатель городской думы, а ныне председатель профкома градообразующего предприятия: В чем плюс этой команды? Они активно вписываются во все проекты, в любые источники финансирования. Делают они это весьма активно и успешно. Почему у них получается? Ответ прост: лидер определяет фокус всей команды.

Сам глава городского округа оценивают сегодняшнюю свою команду достаточно высоко: Та команда, которая есть, вполне профессиональна. Она меня вполне устраивает. Особенно те, кто находятся в моем 
топе. Но в нем только 5-7 человек. Остальные, как он считает, - это «люди-функции», на которых «рассчитывать нельзя». Главный принцип, которым он руководствовался при формировании команды - мотивация, желание работать: Если человек готов работать и днем, и ночью, это мой человек.

В сегодняшней ситуации он намерен вводить в команду новый людей, хотя и признает, «людей брать негде», тем не менее, именно это предстоит сделать сегодня: Мы сейчас начинаем кадровую работу по привлечению новых сотрудников. Часть сотрудников мы будем привлекать со стороны. В том числе из других городов. Я их намерен привлекать всеми своими ресурсами - детские садь, школа, образование, квартиры, машины, ... зарплата. Важно дать им стимул для развития. Это не та работа, которая заканчивается. Это перманентная история.

Следует признать, что работа по дальнейшему формированию состава команды признается необходимой людьми из близкого окружения главы, однако планы главы представляются им нереалистичными: Идея главы привлекать тюдей со стороны хорошая, но не сможет он обеспечить всех. Сама идея классная. Можно врачей привести. Можно учителей привести. Надо создавать людей. Но создавать их нужно не только квартирами и зарплатами. Надо, чтобы человеку нравилась его работа. Чтобы он любил этот город. Чтобы он чувствовал себя безопасно в этом городе. В нашем городе нет ни одного ресторана... Нет ни одного молодежного иентра... Мало желающих работать у нас, хоть мы и предоставляем квартиры... Надо быть реалистами, - восклицает председатель думы городского округа.

Столь же критично он оценивает действующую команду главы: С командой у главы есть проблемы. С одной стороны, многие проверены временем. Кому можно доверять, кому нет. У кого амбииий нет, но он всегда рядом... Глава слишком к ним привязан... Он сильно доверяет своему окружению. Я ему периодически говорю: завтра будет другой. Тебя просто предадут, сдадут. Это так и есть. На самом деле с кадрами у нас в городе очень плохо, - уверяет одна из самых влиятельных фигур во вновь созданном городском округе, председатель городской думы, которого многие называют «серым кардиналом».

Осторожное отношение к команде демонстрирует и хорошо известный в городе предприниматель, авторитетный депутат в объединенной городской думе: Глава поначалу взял людей, которым был обязан. Я не могу на это закрыть глаза. Я знаю многих замов. Когда они 
шли к победе, это была одна команда. Мь за правое дело, нам неважно, сколько работы. Когда объединились, вдруг пришло понимание ответственности... Сегодня в этой команде есть раздрай. И довольно сильный.

Раздрай возник не на пустом месте. Скорее всего, он связан с неровным составом команды. С одной стороны, в ней представлены высокие профессионалы, знающие свое дело, с другой - слабые руководители, которым до определенного периода удавалось скрывать свой непрофессионализм за счет преданности главе: Если раньще можно было скрыть свой непрофессионализм, то сейчас это вылезло. Сейчас есть люди в администрации, которых не интересует жизнь в городе. Нужны те, кто будет делать изменения. Главе придется принимать решение, близких ему не профессионалов надо будет менять. У него не хватит смелости, убрать человека, который был с ним пять лет. Это сложно убирать людей, которые проработали с тобой столько лет, - убежден депутат. Подобные ошибки, считает наш информант, допускали и его предшественники.

Изменения, по мнению депутата, особенно необходимы в связи с тем, что депутатский корпус в городе стал более требователен к власти, поэтому теперь чиновникам надо не просто приказывать депутатскому корпусу, а согласовывать с ним свои решения: Меня радует то, что власти исполнительной придется делать то, что скажут депутаты. Мь будем говорить о необходимости эффективно использовать бюджет. Мы будем влиять на решения главы и на него самого. Хотя он не отрииает проблем в городе и команде: скажете, я сделаю, хотите - поменяю команду.

Некоторые наши информанты из близкого окружения главы высказываются о сформированной команде и действиях главы по ее формированию еще резче. Причем оценки эти идут от топовых руководителей, которые составляют ядро команды: Глава не создает команду. Он дает указания. Для него человек - это функция. Если ты руководишь, надо создавать команду. Ты все равно один можешь что-то упустить. Ть должен уметь рисковать и одновременно доверять, не обязательно всем. Ты должен окружить себя профессионалами. Не бояться, что окружение может что-то знать лучше тебя. Многие боятся брать $\kappa$ себе на работу таких людей... Это неправильно, - убежден многолетний член команды главы и его партнер, бывший сити-менеджер города, а ныне заместитель главы городского округа. 
В чем, на взгляд заместителя, основной недостаток главы, если речь идет о команде: На сегодня глава все сферы пытается курировать. Это много. Я ему постоянно говорю о том, что не надо этого делать. Люди так и не научатся принимать самостоятельные решения. У главы нет команды: в этом его минус. Он в этом никогда не признается. Но это есть.

Видимо, длительное время совместной работы в команде дает право заместителю главы городского округа высказывать столь жесткие оценки, однако не исключено, что причиной отрицания наличия команды является разный взгляд на ее структуру и выполняемые функции.

Проведенный анализ скорее свидетельствует о том, что ядро команды сформировано, в то время как второй ее эшелон явно требует обновления. Этого, кстати, не отрицают и глава, и его ближайшее окружение. Факт неоправданного стягивания на себя полномочий команды действительно не самый эффективный способ управления, тем не менее, взвалив на себя новый груз ответственности управления расширенной территорией, глава вполне оправданно «осторожничает», так как сам пока плохо представляет, как будет работать управленческая машина в изменившихся условиях.

Данный кейс ярко подтверждает тот факт, что даже сильный глава с большим управленческим опытом в условиях малого города не способен быстро сформировать команду. Главное, что причина кроется не только и не столько в дефиците кадров, как думают многие, сколько в неумении главы отказаться от привычных для себя способов формирования команды. Даже при наличии планов, ориентированных на развитие города, главе трудно отказаться от принципа лояльности в пользу компетентности членов команды. Не исключено, что доверие к членам команды и нежелание не оправдать их ожидания может дорого обходиться власти. В этом случае ужесточение критериев подбора команды - необходимый шаг, иначе процесс командообразования будет сильно затянут.

Проведенное исследование показывает: смена слабого главы на сильного позволяет подобрать и более эффективную команду, однако ее безусловное усиление происходит лишь при условии, что удается сформировать не только ядро команды, но и ее периферийные зоны. Это оказывается непростым делом, потому что предполагает новый взгляд на привычные процессы, происходящие в команде.

Важный вывод, который следует на примере данного кейса - модель «солидерства», даже при сильном главе, может быть реализована лишь 
частично. Это означает, что стартовые возможности для начала ее реализации вполне сложились, но впереди большая работа, требующая огромных усилий со стороны самого главы и всей его команды. Самое трудное - убедить главу, что делиться лидерством с командой, это залог будущего городского развития.

\section{Город А: когда команда формируется...}

Данный кейс позволяет убедиться в том, что линия поведения глав в отношении команд, доставшихся им от прежнего главы, может различаться. На примере города А мы увидим, что иногда новый глава осознанно хочет опираться на старую команду, оставив в ней ранее работавших замов, несмотря на то что смена лидера всегда неоднозначно сказывается на команде. В большинстве случаев такой вариант приводит к замедлению процесса формирования команды, с одной стороны, с другой - такой выбор, несмотря на сложности, позволяет удержать в команде профессионалов, которых в условиях малого города найти достаточно сложно. От нового главы требуется терпение и доверие к старым членам команды, что повышает вероятность позитивного прогноза работы команды.

В городе A, на момент первого этапа исследования, глава администрации, как и принявшие участие в исследовании городские локальные элиты, оценивали профессиональный уровень команды тогдашнего главы как «средний». И это несмотря на то, что глава администрации в 2003 г. пришел к власти, а покинул ее в 2015 г. Завоевав место во власти, по оценкам респондентов, он начал смещать ранее работавших заместителей и заменять их своими кандидатурами ${ }^{1}$.

Все эти годы пришедший руководитель города «тянул» команду, заменяя менее компетентных работников профессионально более подходящими кандидатурами, но достичь высокого уровня компетентности команды ему так и не удалось. Зато удалось сплотить команду и сформировать в ней необходимый комфортный уровень для совместной работы. Члены команды единодушно признавали: Mь одна команда.

Тем не менее, интервью, проведенные почти семь лет назад, показали: реальная власть по принятию ключевых решений была сосредо-

${ }^{1}$ По иронии судьбы действующий сегодня глава как раз был тем смещенным заместителем по социальной политике, который вернулся во власть вновь, спустя 12 лет, но уже в должности первого лица власти в городе. 
точена у главы администрации, а члены команды являлись лишь исполнителями, имеющими право высказать свое видение сложившейся ситуации, никто из них не обладал высокой степенью автономии и не играл самостоятельной роли в локальной политике. Хотя «демократичность» главы администрации предполагала «согласовательную модель» работы с командой, которая, согласно полученным оценкам, вполне удовлетворяла тогдашних работников администрации. Глава считал возможным советоваться с ними, но окончательное решение всегда принимал самостоятельно, предварительно потратив дополнительные усилия на убеждение членов команды в своей правоте. И ему практически всегда это удавалось.

Некоторые оценки дают основание утверждать, что модель взаимодействия главы с командой лишь маскировалась под «согласовательную», на самом деле оставаясь авторитарной.

Сам глава администрации называл свою модель принятия решения «коллегиальной», хотя лица, наблюдающие за работой команды со стороны, не всегда с этим соглашались. Влияния городских чиновников нет. Каждьй боится пойти в обход главы администраиии, - утверждала несколько лет назад одна из депутатов городского совета. Высказанной позиции оппонирует сам глава администрации: Я самостоятельно решений не принимаю, но последнее слово всегда остается за мной.

Большинство представителей городской элиты полагало, что команда главы администрации в целом была способна решать городские проблемы: В команде есть слабые звенья, но в иелом это работаюшая команда. Причина одна: глава администрации держит руку на пульсе. Он понимает, где и что у него есть. Он умеет заинтересовать людей. С ним интересно работать. Он непредсказуем, хотя во всем опирается на законы, - замечает депутат городского совета.

Таким образом, в А несколько лет назад была выстроена структура власти, в центре которой находился сильный глава администрации. Он смог сформировать оптимальные отношения со своей командой, которые строились на «невидимом авторитаризме», воспринимаемом членами команды как взаимное доверие и уважение. Высокий авторитет главы администрации и компетенции позволяли ему стабильно добиваться принятия необходимых решений и одновременно учитывать мнения членов команды, которые ощущали сопричастность к данному процессу, но не пытались играть в нем самостоятельную роль. Работая над улучшением состава команды почти 12 лет, он, тем не менее, не соз- 
дал идеальной команды, где каждый специалист и руководитель был бы необходимым и надежным звеном.

Важно, что команду при этом не раздирали идеологические или иные противоречия, хотя утверждать, что между членами команды не было конкуренции «за внимание шефа» все же нельзя.

Пришедший в 2015 г. новый глава отличался от своего предшественника по многим основаниям. Но главное, что их объединяло, - комсомольское прошлое. Именно оно предопределило тот факт, что многие способы работы с командой были сохранены. Новый глава, в отличие от своего предшественника, разбирался с оставшейся командой весьма осторожно, несмотря на то, что проголосовавшие за него депутаты городского совета были настроены весьма решительно. Они настаивали на том, чтобы старая команда была сменена полностью. Ответ на предъявленные требования со стороны депутатского корпуса новому главы пришлось искать, используя компромисс: У меня работники прежнего главы остались. Некоторых я убрал. Бьло пакетное соглашение. Депутать мне сказали - этого убрать, этого убрать. Я сказал, нет ребята... Тогда работайте сами. Давайте договариваться.

Когда переговоры зашли в тупик, глава заявил о своем возможном уходе: Мне депутатские группь стали диктовать, кого брать, а кого нет, и переговоры зашли в тупик. Я сказал, все я поехал обратно. Уменя есть повод губернатору сказать, что я не гожусь. Если Вы хотите, чтобы я работал - тогда я сам буду выбирать свою команду. Мне нужны профессиональ. Это было мое условие. И председатель комитета по имуществу, и председатель комитета по образованию, и председатель комитета по культуре из старой команды, сейчас у меня работают.

Объясняя причину, по которой он бился за членов старой команды, глава замечает: У губернатора такой подход к своей команде. И у меня точно такой же подход... Где я людей возьму, где я возьму управлениев? Моя задача была - их на свою сторону перетянуть, объяснить им, что у меня нет икурных интересов... Если у меня нет своих интересов, они знают, что я им не дам их интересь реализовывать.

Оценивая сегодняшнюю команду главы, бывший мэр, а ныне депутат областного собрания замечает: У действующего главы команда делится на людей, ориентированных на прежнее руководство и на настоящее. Это не идеологические разногласия. Они все представляют ЕР. Это бьвает всегда, когда приходит один руководитель и уходит другой. 
Является ли это непреодолимым препятствием, для того чтобы продолжать работать вместе с этими людьми в одной команде? Похоже, что нет. Именно так считает бывший мэр, хотя и настаивает на необходимости работать с такой командой весьма осторожно: Я не против, итобы в команде были люди предшественника. Но не торпедируйте решения, и не мешаите реализовывать ту линию, которая проводится. Дружите, пейте, гуляйте... Вопросов нет. Голосуйте за прежнего главу в Думу. Это Ваше право. В команде скоро будут изменения. Но не по принципу «старые - новые» Есть новые тренды, в которые некоторые сотрудники не впишутся.

Подтверждает высказанную оценку и сам действующий глава города, которому в сложившейся ситуации совсем непросто. Тем не менее, он остается верен выбранной линии, хорошо осознавая возможные риски подобных шагов: Когда пришел к власти бывщий глава, он всю команду вычистил, включая меня. Не осталось ни одного человека. А я всех оставил. И многие из них поняли, и согласились со мной работать. Некоторые ушли... Но остались и люди из прежней команды.... Их с каждым годом становится все меньше, и меньше. В первые годы такими были почти все. Сегодня это не так.

Стремление главы улучшить команду строится не только и не столько на том, чтобы убрать из нее приверженцев бывшего главы. Основное - добиться того, чтобы команду составляли люди, ориентированные на перспективу. И такие люди в команде есть, но их должно быть значительно больше: Я все же команду потихоньку обновляю. Потому что есть люди, которые видят перспективу, и есть те, кто этого делать не умеет. Я их так называю - ясноглазый и неясноглазый. Неясноглазые - это те, кого в 5 часов вечера ветром сдувает... Но есть те, кто проявляет какой-то интерес. Я им тогда что-то рассказываю. Иногда и неясноглазым рассказываю. В известном смысле я заложник кадрового дебицита, который существует в небольшом городе всегда.

Формулируя свои принципы работы с командой, он замечает: Я оставляю право для всех людей жить и работать по своим внутренним приниипам. Моей сверхзадачей было, когда я здесь оказался, чтобы эти люди, олигарха или бывшего главы, чтобы их уравнять и мотивировать к работе. У меня других людей не будет. Мне сюда с Марса людей не завезут.

То, что глава работает с командой внимательно, постоянно пытаясь усилить ее состав, признает и заместитель главы по социальным вопро- 
сам, приверженец бывшего главы и в известном смысле оппонент действующего руководителя: Действующий сегодня глава оставил много опьтных людей из прежней команды. Ему надо работать одновременно смолодежью, и с нами, людьми возрастными. Мы привыкли за 13 лет работы к определенному стилю. К определенным методам работь. К определенной линии, которая выработалась. Новому главе выитии за рамки сложившихся правил очень сложно. Тем не менее, я считаю, что в коллективе - мь нашли понимание.

Осознанное нежелание к радикальным переменам в команде, в противовес которым он использует стратегию постепенного втягивания коллег в новые принципы работы, сам глава комментирует следующим образом: Почти 4 года, которье я работаю, я собираюсь выгнать начальника МЧС. Он абсолютный солдабон, ничего не понимает. Но он хочет рулить. В тоже время, я понимаю, что я его выгоню, а на его место возьму точно такого же. В лучием случае. А так может быть будет кандидатура еще хуже. Я же новых людей не создам. У человека будет возможность сказать, - я не знаю, меня тогда не было. Какой смысл выгонять и менять?

Сформированная главой команда сегодня является его помощником в сложных ситуациях и, похоже, разделяет его принципы: Mы помогали главе, когда он весь ушел в проблемь предприятий в городе. В основном они были из-за невыплаты зарплать... Я видела, что он весь там настолько... И кроме него этого никто не сделает... У заместителя по экономике, который только пришел, у него не было опьта и знаний... А я здесь как могла держала ситуацию. Это главное... в команде. Уметь на себя взять груз тех проблем, которые пока не находятся в иентре внимания, но решение которых необходимо, - считает заместитель главы по социальным вопросам.

Возникает естественный вопрос, могут ли старые члены команды обеспечить новые вектора развития с новым главой, повысив тем самым эффективность муниципальной власти?

Оценки, полученные в ходе интервью на этот счет весьма противоречивы. Эксперт-социолог, работающий в областной администрации, убежден, что такое вряд ли возможно: В иелом у нового главы в городе А команда осталась та же самая. Он пьтается ее менять, но где взять других людей? В условиях малого города, где взять людей, которые досконально знают городское хозяйство? Разве можно что-то сильно изменить, если ты стоишь над Васей, а Вася один и тот же? Tы вь- 
носишь одно решение, второе решение, которое команда не поддерживает, и ты останавливаешься, ты не в состоянии ничего изменить... Они будут делать, но спустя рукава... Или просто саботировать распоряжения главы... Зарядить команду на успех - очень трудно... Это и есть задача главы. Здесь могут иметь значение его тичностные качества. Если он лидер, у него это лучше получится. Но ресурсы, то есть люди, работающие в команде, их мотивация, все равно важны.

Сам действующий глава города А с высказанной позицией явно не согласен: Можно ти при старой команде создать новые вектора движения? Добиться новых достижений? Сомневающимся отвечу, но ведь это случилось. Хотя у меня была старая команда.

Не исключено, что правы оба информанта. Все зависит от лидерских качеств самого главы. Если он способен достичь управляемости своей командой, даже при известном сопротивлении, то прорыв обязательно случится. При хорошей ресурсной базе он будет более значительным. При дефиците он будет локальным, но все равно будет. Отсюда вывод управленческие умения и лидерские качества главы иногда важнее ресурсной базы, которая сложилась, но, если эти два фактора присутствуют одновременно, тогда успех обязательно станет реальностью.

Таким образом, пример города А вновь позволяет убедиться в том, что в условиях малого города формирование команды - непростой процесс. Идет ли речь о дефиците, или о несогласии депутатского корпуса сохранять тех или иных людей в команде. Ясно одно - способность главы ориентироваться на профессионалов, а не на новых «своих» кандидатур весьма важна, однако эта стратегия весьма затратна и совсем необязательно быстро приводит к нужным результатам.

\section{Город Z: возвращение во власть}

$\mathrm{B}$ городе $\mathrm{Z}$ сложилась уникальная ситуация для изучения командных процессов. Глава администрации, отправленная в отставку четыре года назад, на момент проведения второго этапа исследования, вновь стала главой города по распоряжению нового губернатора. Благодаря этому кейсу нам удалось проследить, какие шаги предприняла глава для формирования своей новой команды по возвращению во власть, стремилась ли она восстановить прежние фигуры в команде или сориентировалась на новые персоналии?

$\mathrm{B}$ городе $\mathrm{Z}$ на момент первого исследования глава администрации, позже вернувшаяся во власть, но снятая через полгода после начала 
первого этапа исследования, достаточно критично оценивала членов своей команды, как и локальные элиты.

По мнению элит, уровень профессионализма, активности, инициативы и других параметров деятельности команды городской администрации в целом оставался весьма низким. Причину этого элиты видели не только в дефиците кадрового ресурса, вполне типичного для малого города, но и связывали с определенными принципами подбора кадров. «Личная преданность вместо компетентности» и «свой человек предпочтительнее профессионала», — так они формулировали суть кадровой политики главы администрации города.

Ориентация на своих породила отсутствие инициативности команды, которую чувствовала не только сама глава администрации, но и представители местных элит, взаимодействующие с членами команды.

Ориентация «на своих» у главы администрации, была обусловлена не только стремлением иметь послушную команду, но и возможностью взять под контроль денежные потоки, в том числе неформальные.

Принятие решений внутри команды главы администрации Z было вполне традиционным и строилось на принципах полного подчинения главе администрации, при этом автономия членов команды была сильно ограничена.

Тем не менее, в команде присутствовали как минимум два человека, которые претендовали на инициативные действия, но так и не смогли противостоять главе.

Небезынтересно отметить, что сама глава вполне осознавала недостатки и ограничения в деятельности своей команды, потому что «людям, проще делать то, что всегда». Хотя и была убеждена что моноцентризм - единственно возможный способ управления в сложившейся ситуации.

С ней был не согласен предприниматель и секретарь местного отделения партии ЕР, который видел в ее шагах по работе с командой в те годы много несоответствий с тем, как это должно было быть на самом деле: Когда она начинала во власти, мы с ней очень плотно общались, чуть ли не каждььй день встречались... Нарезали задачи, обсуждали... У нас вообще не бьло тайн. Ей нравилось, когда люди ей улььбаются, открывают дверь... И она готова была это поставить на первое место в человеке. Я человек прямой. Я ей говорил, что это не так. Ей это не нравилось. И не важно, - сдам я или не сдам... Для нее это было 
на втором плане. У нас с ней отночения сохранились, но мьи чуть-чуть разошлись в дальнейшем.

Сама глава не разделяла точку зрения, что ее окружают исключительно слабые профессионалы с низкой мотивацией; при этом подчеркивая, что кадровый ресурс малого города ограничен: Я пришла, а руководителей нет. Практически никого не было, их пришлось искать повсюду.

Трудно с этим не согласиться, хотя бы потому, что после ее снятия с должности вновь пришедший глава так и не смог нарастить потенциал своей команды, а скорее его снизил, что привело к серьезным негативным последствиям в городе.

Оценки местных элит относительно команды сменившего ее главы весьма отрицательные. Одни говорят о том, что «пришедииц̆ глава разогнал многие отдель в администрации», другие с возмущением напоминают о том, что «сам глава и его заместитель (человек главы) просто врали всем, что они в городе сделают, бактически парализуя работу командьı».

Косвенным свидетельством того, что прежний глава разрушил все то, что создавалось до него, является свидетельство вернувшегося во власть сегодня заместителя вновь назначенной главы города по финансам: После ушедшего главы одна разруха Вообще ничего не осталось. В 2013 году хоть что-то было. Кадры, коллектив... А сейчас вообще ничего нет. Не знаю, за что хвататься. Как Мамай прошел, - с горечью замечает она.

Это означает, что финансовый блок работы команды был полностью провален, что не могло не отразиться на других рабочих направлениях, за которые отвечала команда.

К моменту возвращения прежней главы во власть требовалась большая работа с командой, которая за годы «безвременья» была просто парализована и разучилась работать в нужном темпе. Первый шаг, который сделала глава по приходу во власть, - восстановила часть своей прежней команды: Команда была частично восстановлена, после того как ее «зачистил прежний глава. В нее вернулись три человека. Однако сейчас задачи изменились по сравнению с более ранним периодом. Сегодня им не хватает темпа. Я просто натыкалась на стену непонимания. Сейчас этот маховик раскрутился. Они под меня подстроились. Сейчас понимания больше. И они ускорились значительно. 
Формулируя принципы подбора кадров для команды, она на первый план выдвигает такие качества, как работоспособность, инициативность и компетентность: Мне сейчас нужны люди, которые будут работать и днем, и ночью. Причем абсолютно бескорьстно. Выполняя любую работу... Люди должны быль инициативные и грамотные. Мне надо сначала вернуться на старую ступеньку, а потом сдвинуться с мертвой точки. И двигаться вред. Для этого надо работать и днем, и ночью. Иначе мы долго-долго не вернемся к старой отметке.

Признает необходимость корректировки команды вновь пришедшей главы и ее прежний соратник, известный в городе предприниматель, бывший секретарь местного отделения партии ЕР: Я знаю всех членов ее командь И как житель города, и как участник политической жизни. С чем-то я согласен, с чем-то нет. С чем-то категорично нет. C отдельными личностями. Именно из-за уровня их профессионализма. Сейчас надо команду заново собирать. Прежний глава разогнал многие отдель. С учетом фонда заработной плать - это все настолько грустно... Но команду все равно надо бормировать. На это уйдет долгое время. Чтобы вырастить специалиста в любой области надо как минимум год. Молодежь не очень хочет работать Им надо денег сразу и много.

О неоднозначности восприятия сделанных перестановок в команде со стороны местных политиков говорит председатель городской думы, тем не менее, убежденный в том, что лучше на данном этапе справиться с этой задачей было нельзя: То, что она возвратила старую команду, воспринимается неоднозначно. Есть фигурь, которье воспринимаются неоднозначно. Но я поддерживаю их возвращение. Некогда молодьх учить. Понятно, что вернувшимся замам... тяжело. Представьте, после тропических дождей одни аварии. Заместитель по благоустройству говорит мне - трудно втянуться, хотя прошел уже практически месяи. Столько всего! А начинать надо с нуля.

Конкретную работу по доводке команды до нужного уровня планирует провести, и уже начал это делать, вновь назначенный руководитель аппарата городской администрации. По его мнению, последовательность шагов, которые необходимо сделать, понятна уже сейчас: Нужна команда, и ее надо создавать... Ее надо учить. Надо, чтобь команда шла вперед, для этого ее надо подтягивать... Надо провести мониторинг, понять, что знают специалисты разных подразделений... Я знаю, что и как надо делать, чтобь была нормальная команда... 
Пусть это команда прежнего главы с добавлением новых фигур... Надо посмотреть, где были провалы... Дать команде работать, зажечь ее, независимо от того, под каким руководителем она работала раньше.. Если совсем антагонистьы, то они, естественно, работать не будут... Главная задача - сделать так, чтобы в городе был прорыв. Для этого работник каждый день должен приносить какую-то пользу... А не просто отсиживаться на работе... Он должен нести ответственность... и делать лучше для людей, живущих в городе.

Первые шаги по восстановлению работоспособности команды уже были сделаны, но их нельзя признать достаточными: Для меня сейчас важно понять, сможет ли эта команда двигаться вперед? Я пока на 100 \% не могу этого сказать. Я послушал руководителя территориальной комиссии, начальника управления организачионной работы, кадровой службы, системного администратора, и др. Они пришли ко мне в кабинет, все напряженные и зацикленные... В процессе разговора у них глаза загорелись... Через некоторое время я почувствовал обратную реакиию. Весь аппарат должен работать, на задачу, которую ставит глава. Здесь, и участие в федеральньх программах... Надо чтобы все они владели способностью работать с информационными программами. За работником надо смотреть, может его на какой-то другой участок следует передвинуть... я хочу дойти до каждого сотрудника и с каждым поговорить. Это важно, итобы понять слабые стороны администрации. Без этого ми не сможем продвинуться вперед. Самое главное, чтобы у этих людей была ответственность. За те решения, которые мы вырабатываем... Меня что поразило, - их спокойствие. Нюха у них пока нет.

Действия нового руководителя аппарата поддерживаются депутатским корпусом. И это не случайно. Он смог внятно расставить приоритеты и согласился с тем, что власть исполнительная лишь исполняет то, что предлагает власть законодательная: Мне нравится руководитель аппарата. Он человек новый... Он собрал аппарат городской думы и сказал, вы законодатели, а мы исполнители... И по-другому никак не должно быть. Когда он пришел и увидел, что нет ответов на 186 писем, он быстро включился в работу. Ведь это народ, со своими просьбами и обидами.

Итак, проведенный анализ ситуации с кадровыми перестановками в команде старой главы, вновь вернувшейся во власть в городе Z, убедительно свидетельствует о том, что даже сильный и мотивированный 
лидер не может справиться со всеми задачами, если его команда не сформирована. Поэтому первое, что делается, - восстанавливается команда. Хотя сделать это не так просто. Данный кейс убеждает в том, что проблема состава команд и уровня профессионализма, особенно ключевых замов, остается приоритетной на всех этапах работы любого главы города. При этом время все более требует менять принципы подбора команды не в сторону лояльности, а в профессиональном направлении. Дефицит профессионализма в малых городах столь велик, что незначимыми являются даже такие важные параметры отбора, как возраст и образование. На первый план выдвигаются опыт, умение достигать поставленных целей, ориентация на конкретные результаты, высокий мотивационный уровень, выраженная работоспособность.

Рассмотренный кейс города $\mathrm{Z}$ позволяет убедиться в том, что персональные стратегии и личность главы очень важны при формировании команды. Мотивация команды во многом определяется тем, кто возглавляет команду. Даже в том случае, если глава уходит, но потом возвращается, его последователи могут вновь пополнить команду, несмотря на свои личные предпочтения. Вопрос о том, могут ли члены команды в такой ситуации взять лидерство на себя, остается открытым. Не исключено, что в ситуации повторного становления команды это будет зависеть не только от уровня профессионализма ее членов, но и от характера поведения самого главы. Если глава склонен к тотальному контролю над членами своей команды, то эффект «солидерства» не возникнет, даже если команда будет готова работать по этой модели.

\section{Команда главы G: последователи сформированы, но...}

В городе G исследование проводилось только в 2020 г. Однако все командные изменения на протяжении последних десяти лет мы пытались зафиксировать в проводимых интервью, ставя перед информантами задачу: рассказать, что именно происходило с командой десять лет назад и что происходит сегодня.

Важно подчеркнуть, что если сегодняшнее состояние команды воспринимается как вполне достойное, то почти десять лет назад это было совсем не так. Сегодняшняя хорошая команда - результат усилий прежнего главы, ныне министра территориального развития краевого правительства, который, придя к власти, начал изменение ситуации в городе с формирования своей команды по новым принципам: Пришедшего в 2012 году главу сначала района, потом вновь образованного 
городского округа поддерживали, и многое в городе стало происходить позитивного. Люди это увидели сразу. Он прекратил войну между властью и компанией М. Он захотел сделать власть результативной. Это ему удалось. Ему пришлось пойти на очень непопулярные меры. Он перетряхнул администрацию. Очень хорошо их тряханул. Его девиз: «Вы работаете, если не можете - учитесь, если учиться не можете - уходите». Он нашел сити-менеджера, который после его ухода возглавил городской округ. С тех пор и до сегодняшнего дня город в числе первых по вхождению в различные проекты. У нас сразу проспект отремонтировали. Начали стройку. Очень многое сделали по благоустройству города. Раньше трава была по пояс. Была разруха... Теперь ты заезжаешь в город и видишь, пусть маленький, но уютный городок. Вполне себе современный. Даже с маленьким фонтанчиком. Со своей Красной площадью. Маленькой. Зайдите в парк Гагарина и посмотрите. Это только начало, - делится своими воспоминаниями один из наших информантов.

На вопрос о том, сформирована ли сегодня у главы города G команда, подавляющее число респондентов дает положительный ответ, включая самого главу. Важно, что такую оценку дают как сами члены команды, так и те, кто в нее не входит. Высокие оценки команды, в которой работают сотрудники администрации, достаточно распространенное явление, однако в данном случае они имеют выраженно позитивный характер с элементами гордости за свою команду и свою работу: У нас хорошая команда. Я горжусь тем, что я в ней работаю. Мне странно, что может быть как-то иначе. Ведь хорочая команда - это оценка главы в первую очередь, ведь это его команда. Можно сказать, что мы все идем за главой и вместе с ним. Людей, которые не лояльны, в команде просто нет. Даже если они раньше были, - убеждена начальник управления внутренней политики и организационной работы.

К высказанному мнению присоединяется и начальник управления культуры, которая подчеркивает важное качество главы - способность помогать членам команды в реализации задуманных ими проектов: У главы есть команда. Это безусловно. Любое начинание, которое глава привносит, командой поддерживается. Если мы хотим что-то сделать..., мы знаем, что он нас поддержит. Он найдет нужные связи, в том числе в крае, чтобы нам помогли задачу реализовать. Или найдет помощников на градообразующем предприятии.

Основным достоинством команды, по ее мнению, является способность к взаимодействию между различными управлениями, что позво- 
ляет более динамично реализовывать городские проекты. Высказанная позиция хорошо согласуется с тем, о чем в своем интервью говорит начальник управления внутренней политики: Когда к нам приезжают сотрудники из других муниципалитетов и видят наши взаимоотношения на любом мероприятии, они подчас удивляются. Отношения между членами команды все равно видны. Как и связи, которые есть между управлениями, между учреждениями, которые им подведомственнь. Все удивляются, но мне удивительно, как это может быть подругому. Мне говорят: у нас нет такого взаимодействия... между культурой и образованием. Между культурой и коммунальной сберой. А я не понимаю, как можно по-другому работать. С тем же образованием. Что мы без них, и что они без нас?.

Работа команды не осуществляется автоматически, ее надо сформировать исходя из стратегии развития: Когда человек видит траекторию развития территории, он подбирает команду, которая к нему подстраивается. Он формирует команду единомышленников. И команда идет с ним в одном направлении, когда задачи поставлень. Наша команда сформирована именно таким образом еще в 2013 году, - напоминает руководитель управления экономики городской администрации.

Но и это не все. Необходимо пополнять команду, подбирая новых сотрудников, поддерживать мотивацию членов команды, обеспечивая им карьерный рост. Похоже, что с этим глава и остальные руководители управлений вполне справляются: В формировании команды все участвуют. Люди, которые приходят ко мне на работу в управление, согласуются не только с главой, но и с заместителем. От меня зависит рекомендовать или не рекомендовать человека. У нас из управления много людей ушло на повышение в наших структурах. В муниципальные учреждения. Они здесь выросли как специалисты. Почему у нас растут сотрудники? У нас большой круг общения. Когда они проходят школу постоянного общения со специалистами разного уровня, в том числе с предпринимателями, они становятся другими, более востребованньми людьми, - заверяет начальник управления экономики.

Городские предприниматели, в свою очередь, оценивают работу городской команды как результативную, связывая это с ее обновлением. Вот что думает один из них: У нас в городской администрации сегодня есть команда, которая работает сообща... Правильно бывиий глава сделал, - команду поменял, посадив туда людей, которые могут 
работать. Много лет старые сотрудники ничего позитивного не делали. Уже и работать не хотели... И мыслили по-старому. Сегодня команда - это ресурс для развития города. Без этой командь, которая сегодня есть в администрации, глава один ничего бы не сделал. Взаимодействие в команде, общее видение иели- обеспечивает эббективность управления и позволяет достигать результативности при реализации проектов.

Сам бывший глава, а ныне министр территориального развития признает, что ему пришлось кардинально поменять состав команды в 2012 г., чтобы начать преобразования, которые впоследствии привели к заметным позитивным изменениям в городе. Я пришел и поменял команду практически иеликом, процентов на 80 \% Где я брал новых работников? Людей доставал из темных углов. Люди всегда есть, надо уметь их разглядеть. Специалистов толковых, которые работали в администрации, подтянул наверх. Вот так и получилось.

Но есть и более осторожные оценки действующей команды: Мне кажется, что команда разная. Если взять сферу ЖКХ, то там сложно. Там присутствует апатия. День прочел и ладно. Те, кто в аппарате, те с желанием работают. Иначе просто надо уходить. Зачем ходить на работу, если нет живого настроения? Яркости в глазах?

Подтверждает тезис о том, что команда не идеальна, и главный редактор местной газеты: К управлению ЖКХ в команде больще всего вопросов. Я понимаю, бывая на аппаратных совещаниях, ито есть вещи, о которых они просто умалчивают. Глава не спросил - , слава богу. Какие-то нереализованные вещи переходят из недели в неделю. Отчитались, что сделали, идешь смотришь - не сделано. Не все так идеально.

Следует заметить, что к моменту нашего исследования, видимо учитывая критику, глава поменял своего бывшего зама по ЖКХ на нового, который пока не успел себя показать, но с которым члены команды связывают успехи в будущем.

Глава городского округа оценивает свою команду достаточно высоко, полагая, что без команды он не смог бы реализовать все необходимые городские проекты: В приниипе меня команда устраивает. Если бы она меня сильно не устраивала, то я бы не знал, как с ней работать. Команда нужна. Один всего не охватишь. Хочется делать все качественно, тем более что мы работаем в очень большом количестве проектов. Многие процессы надо контролировать. 
Размышляя о принципах формирования команды, он выделяет главные из них, которыми руководствуется в своей работе: Команда для управления городом должна включать подготовленных людей. Готовить людей с нуля у меня просто нет времени. Эта подготовка включает не только исключительно профессиональные навыки. Важны человеческие качества руководителя. Например, умение общаться с людьми. Мне пришлось поменять руководителя ЖКХ, потому что ему не хватало коммуникационных навыков. У него постоянно были конфликты со всеми. С управлениями, с населением. Первый приниип подбора и сохранения в команде - человек помимо специальных знаний должен обладать коммуникативными навыками. Второе - важны ценности человека. Именно из них он выстраивает приоритеть. Мь строим здесь свои приоритеть, и обсуждаем их на уровне правительства. У нас не должно быть разногласий, в том числе иенностных, по выцелению приоритетов. Иначе член команды будет противодействовать работе, и тогда ничего не получится.

Глава города достаточно осознанно работает с теми, кто не смог вписаться в коллектив: Я весьма жестко работаю с теми, кто способен подстрекать свой коллектив. Таких я сразу убираю, я с ними не разговариваю. Их сразу видно по настроению. По мотивации. С мотивацией надо уметь работать, и понимать, как она строится у человека, зависит ли она от внешних причин, или ему важнее самого себя уважать. Если я доверяю человеку, и даю ему свободу действий, это его мотивирует. Он сам принимает решения. Сам их реализует. И сам получает удовольствие. Я не давлю, и не проверяю каждый шаг. Самостоятельность - это важно, ее нельзя недооценивать. Людям нравится быть самостоятельными.

Отличительной особенностью ситуации, которая сложилась в городе $\mathrm{G}$, является тот факт, что команда главы не ограничивается городской администрацией. В нее по факту входят и руководители компании M, и депутаты краевой думы, и председатель думы городского округа, и даже министр территориального развития. Такая конструкция команды помогает привлекать дополнительные ресурсы в город и реализовывать приоритетные проекты. В этой связи рамки команды расширяются, а следовательно, управление такой командой значительно усложняется. Именно так считает глава: Чем команда сплоченнее, чем большее число уважаемых людей со стороны в нее входят, тем труднее работать главе. Проще работать одному. Глава сам за себя отвечает, 
никто ему не указ. Есть города, где нет депутатов ЗС. Есть города, где директора предприятий вообще не занимаются развитием города. Унас все по-другому. Я постоянно нахожусь в диалоге со всеми. С депутатами 3С, с Правительством, с тем же министром территориального развития, и с Председателем Думы городского округа, и с генеральным директором... Если у меня что-то не получается, то я должен ответить перед всеми, почему так случилось. Это повыиает ответственность, твоя работа постоянно проглядьвается и контролируется. Ть обязан быть эффективным.

Итак, собранный аналитический материал позволяет заключить команда последователей и партнеров в городе $\mathrm{G}$ сложилась. Но все же нельзя утверждать, что ее формирование завершено. Наиболее сложные участки городского хозяйства пока не закрыты окончательно. Тем не менее, расширенный состав команды, ее умение работать с использованием модели партнерства делает ее наиболее эффективной командой в сравнении с теми вариантами, которые были исследованы нами в других городах. Безусловно, когда работа в городе идет вместе с сильным и ресурсным партнером, мотивация у членов команды не может не повышаться. Особенно в том случае, если глава территории умеет быть адекватным и использует приемлемые и взвешенные способы работы со своей командой. На наш взгляд, именно команда в городе $\mathrm{G}$ в наибольшей мере способна через некоторое время действовать по модели солидерства, хотя бы потому, что многие ее члены приучены брать ответственность на себя.

\section{ЗАКЛЮЧЕНИЕ: ТРЕБУЮТСЯ НОВЫЕ ПРАВИЛА ФОРМИРОВАНИЯ ГОРОДСКИХ КОМАНД}

Проведенное исследование процессов командообразования на примере пяти малых российских городов позволило убедиться в том, что пока формирование команд в этих городах является непростой задачей. Первая из причин - кадровый дефицит. Однако, несмотря на то, что практически каждый глава отсылает к сложившейся нехватке кадров, дело не только в ней.

Первое и основное - пополнение команды, как правило, идет за счет сторонников, которые вместе с главой шли на выборах к победе или доказали свою преданность во время совместной работы за пределами администрации. Привязанность к своим людям в противовес компе- 
тентности - довольно распространенный способ отбора команды. Окружение себя своими людьми не столь плохое дело, однако, это работает только в том случае, если свои люди одновременно являются профессионалами. Не менее важную роль играют психологические особенности лидера команды. Нередко скорость ее формирования зависит не от дефицита кадров, а от персональных качеств руководителя, который не может расстаться с преданными людьми из команды, что убедительно вытекает из примера города Ү.

Важный аспект формирования команды - согласие вновь избранного главы работать с членами команды прежнего главы. Как показало исследование, это вариант, который имеет место в практике формирования команд, однако он разделяется далеко не всеми представителями элитного корпуса. Это означает, - глава при формировании команды нередко находится под давлением своих элит. Это наглядно показывает пример города А. Сохранение старой части команды в новом составе - весьма трудное дело, которое возможно осуществить лишь при условии, если глава считает, что это единственный путь сохранения и развития команды. В противном случае подобный шаг лишь затрудняет работу команды из-за постоянных сомнений в правильности сделанного шага и ответного недоверия со стороны тех, кто не ушел и остался на своих рабочих местах.

Весьма интересен пример командообразования в городе Z. Он показывает, что уход главы со своего поста фактически приводит к разрушению команды, особенно если вновь пришедший глава оказывается слабым и немотивированным к работе с командой. Даже если в ней остаются члены команды от старого главы, потеряв лидера, они либо покидают команду (речь идет, прежде всего, о ядре команды), либо остаются на местах, но должной включенности в работу, как правило, не демонстрируют. Вновь вернувшись во власть, глава города $\mathbf{Z}$ была вынуждена вернуть на ключевые посты прежних лиц, будучи уверенной, что только с ними она может реализовать сложные задачи по восстановлению ситуации в городе. Важно, что она смогла извлечь уроки из прошлого срока пребывания в должности. В новой команде глава города поменяла фигуру старого руководителя аппарата, которого не принимали городские элиты, отказывая ему в профессионализме, в момент проведения первого этапа исследования. Вновь пришедший глава аппарата не стремится избавиться от всех прежних членов команды, но намерен оценить уровень компетентности каждого со- 
трудника, а потом принимать решение об их возможности работать в команде нового главы.

Пример города X - хорошее подтверждение того факта, что слабый глава не способен сформировать сильную команду. Способы работы главы с командой весьма важны для ее развития, но если он не заинтересован в росте членов команды, тогда команда быстро теряет интерес к работе, выполняет только необходимые требования со стороны вышестоящего уровня власти и перестает быть заинтересованной в улучшении ситуации в городе. Это приводит к стагнации, и, в конце концов, команда разваливается. Частичные замены ядра команды (новый первый заместитель из бизнеса) способны в принципе привести к переменам, но не всегда приводят к ним фактически. В городе X преобразования в команде начались слишком поздно, главу сняли через два месяца, поэтому увидеть, как смог первый заместитель повлиять на команду, нам так и не удалось.

Город А является своеобразной территорией, которая, на момент проведения и первого, и второго этапов исследования, обладала командой, не отторгаемой городскими элитами, которую они характеризовали как «среднюю». Новый глава, пришедший к власти, оказался в сложной ситуации и не пошел по пути однозначной смены ядра команды прежнего главы. Работать ему в этой ситуации было непросто, но он принципиально хотел добиться от сторонников прежнего главы хорошей работы уже под своим руководством. Это оказалось сложным делом и потребовало терпения обоих сторон. Но все же профессионалы, на которых рассчитывал глава, остались в команде. Важно подчеркнуть, что подобный выбор вполне рационален при кадровом дефиците, однако не гарантирует полноценной работы команды. Силы, отданные на переориентацию команды «на себя», могли бы быть мобилизованы на достижение иных командных целей.

Город G из всех исследованных городов располагает наиболее подготовленной командой, работа которой больше, чем в других случаях, отвечает модели солидерства. Лидер команды использует полицентричную модель власти, доверяет членам своей команды, предпочитая партнерство всем другим моделям взаимодействия. Важно, что и команда доверяет своему лидеру. Для такой команды переход к модели солидерства вполне возможен. Однако пока этот переход осуществился лишь частично. Далеко не все позиции в команде занимают лица с требуемым уровнем профессионализма. 
Ситуация осложняется тем, что команда работает под постоянным контролем со стороны градообразующей компании, что, безусловно, снижает уровень свободы членов команды, так как только лидер команды и иногда его заместитель выстраивают взаимодействие с компанией, тогда как другие члены команды таких выходов на компанию не имеют. Это явно сужает их масштаб самостоятельных действий. В потенциале они могут работать по модели солидерства, но внешние условия им этого не позволяют.

В заключение хотелось бы подчеркнуть: пока ситуация с командами в малых российских городах далека от совершенства. Командное строительство каждого из глав очень зависимо от внешних факторов. Оно усугубляется низкими зарплатами сотрудников, в том числе входящих в ядро команды. Поиск энтузиастов для работы в командах не всегда возможен, тем не менее, наладить эффективную работу команды возможно. Слабый лидер не имеет сильной команды. Отсюда, самый короткий путь к формированию сильной команды - сильное лидерство. Это хорошо подтверждается позитивным примером города $G$ и негативным города X. Консервативность институтов власти приводит к тому, что работа с командами в малых городах строится чаще всего по привычным стереотипным принципам. Однако рутинные практики работы с командами не приносят желаемого результата. Нужны новые подходы и новые решения.

Предлагаемый переход от единоличного к командному лидерству одна из возможных идей оптимизации работы команд. Однако и она пока не может быть реализована в должном масштабе.

Проведенное эмпирическое исследование подтверждает важный вывод: пока городские команды вряд ли могут работать по модели солидерства. Управленческая культура на практике строится по другим образцам, согласно которым лидер остается ключевой фигурой в команде, принимающим все важные решения. Смена управленческой парадигмы потребует времени, но это не означает, что процесс формирования новых ценностей управления командными процессами нельзя начать уже сегодня. Возрастающая ответственность и расширение задач, стоящих перед муниципальной властью, неизбежно приведут к тому, что в команде будет востребован не один, а несколько лидеров, формировать которых нужно начинать сегодня. Необходимо, чтобы принципы работы команд были изменены, хотя бы для того чтобы лидер команды мог более эффективно работать. 


\section{Литература}

Базаров Т.Ю., Рыбкин И.В., Пььркова Т.С. Управленческие команды и их формирование / под ред. Т.Ю. Базарова. М.: ИПК госслужбы. 2009. 51 с.

Белбин М.P. Типы ролей в командах менеджеров: пер. с англ. М.: НIPPO, 2003. 220 c.

Белбин Р.М. Команды менеджеров: как объяснить их успех или неудачу: пер. с англ. 2-е изд. Лондон: Кивитс, 2007. 238 с.

Виханский О.С., Миракян А.Г. Новое тысячелетие: управленческие аномалии и современные концепции лидерства // Российский журнал менеджмента. 2018. № 1. С. 131-154.

Долгов М. В. Особенности управленческих команд на государственной гражданской службе // Вестник РУДН. Серия «Государственное и муниципальное управление». 2018. Т. 5, № 4. С. 365-373.

Долгов М. Модель «5F» - геометрия команды, создающая энергию. Краткое руководство к действию для лидеров. М.: ИП Долгов Максим Валерьевич, 2016. 192 с.

Жуков Ю.М., Журавлев А.В., Павлова Е.Н. Технологии командообразования. М.: Аспект Пресс, 2008. 320 с.

Корниенко В.И. Формирование управленческих команд нового поколения. М.: РАГС, 2000. 150 c.

Лапина Н.Ю., Чирикова А.Е. Регионы-лидеры: экономика и политическая динамика (на примере Ярославской и Самарской областей). М.: Изд-во Ин-та социологии РАН, 2002. 324 с.

Маслюкова М.В. «Золотые правила» менеджмента новой эпохи // Консультант. 2005. № 9. С. 18-25.

Управление персоналом / под ред. Т.Ю. Базарова, Б.Л. Еремина. 2-е изд., перераб. и доп. М.: ЮНИТИ, 2002. 560 с.

Филонович С.Р. Лидерство как интегральная проблема наук о поведении // Российский журнал менеджмента. 2007. № 5 (4). С. 91-100.

Филонович С.P. Теории лидерства в менеджменте: История и перспективы // Российский журнал менеджмента. 2003. № 1 (3). С.3-24.

Чирикова А. Е. Кризис лидерства и новые ценности глобального менеджмента // Персонал-Микс. 2002. № 9. С. 79-88.

Чирикова А.Е. Ледяев В.Г. Власть в малом российском городе М.: Издат. дом «Высшая школа экономики», 2017. 414 с.

Чирикова А.Е., Сельцер Д.Г. Малые российские города: распределение власти между главой города и его командой // Власть и элиты. 2014. № 1. С. 348-384.

Шебураков И.Б. Формирование проектных команд в государственных органах // Управление развитием персонала. 2017. № 1 (49). С. 16-24.

\section{Источники}

Стартовала программа обучения управленческих команд российских городов // Сайт «Сколково». 21.07.2020. URL: https://www.skolkovo.ru/news/startovala-programma-obucheniya-upravlencheskih-komand-rossijskih-gorodov/ (дата обращения: 10.06.2021). 


\title{
TEAMS OF HEADS OF SMALL RUSSIAN CITIES: VECTORS OF CHANGE
}

\section{A. Chirikova}

\author{
(chirikova_a@mail.ru) \\ Federal State Institution of Science, \\ Institute of Sociology of the Russian Academy of Sciences \\ Moscow, Russia
}

Citation: Chirikova A. Teams of heads of small Russian cities: vectors of change. Vlast' i elity [Power and Elites], 2021, 8 (2): 72-112. (In Russian)

DOI: https://doi.org/10.31119/pe.2021.8.2.4

\begin{abstract}
In this article, based on empirical research, the level of professionalism of the teams of heads of five small towns in three Russian regions is assessed. The cases differ significantly, but most of them (4 out of 5) are towns with a difficult socio-economic situation, which has noticeably deteriorated in recent years.

Interviews with key figures in urban politics, business and experts allowed us to describe specific decision-making practices in teams. The assessments of both the team members themselves and the leaders of the executive branch were taken into account, as well as the opinions of persons with experience of interaction with the team and their leaders. The study showed that the practices of distribution of power in urban teams, despite all the similarities, are not universal. Authoritarian forms of interaction with the teams on the part of the municipal leaders remain dominant. The readiness of teams to work according to the "co-leadership" model remains rather low. However, it is possible that with the improvement of the socioeconomic situation and adequate selection of candidates for the post of heads of towns, the situation may change.
\end{abstract}

Keywords: small town, head of the town, the mayor's team, leadership, coleadership" model, team performance.

\section{References}

Bazarov T.Yu., Rybkin I.V., Pyrkova T.S. Upravleniye komandy i ikh formirovaniye [Management teams and their formation]. Ed. by T.Yu. Bazarov. Moscow: IPK gossluzhba. 2009. 51 p. (In Russian)

Belbin M.R. Tipy roley $v$ komandakh menedzherov [Team roles at work]. Moscow: HIPPO, 2003. 220 p. (In Russian)

Belbin R.M. Komandy menedzherov: kak obyasnit ikh uspekh ili neudachu [Management Teams. Why They Succeed or Fail]. $2^{\text {nd }}$ ed. London: Kivits, 2007. 238 p. (In Russian)

Chirikova A.E. Krizis liderstva i novye tsennosti globalnogo menedzhmenta [Leadership crisis and new values of global management]. Personal-Miks [PersonnelMix], 2002, 9, pp. 79-88. (In Russian). 
Chirikova A.E. Ledyaev V.G. Vlast' $v$ malom rossiiyskom gorode [Power in a small Russian town]. Moscow: HSE, 2017. 414 p. (In Russian)

Chirikova A.E., Seltser D.G. Malye rossiiyskie goroda: raspredelenie vlasti mezhdu glavoy goroda i ego komandoy [Small Russian cities: distribution of power between mayor and his team], Vlast i elity [Power and elites], 2014, 1, pp. 348-384. (In Russian)

Dolgov M. Model' «F5» - Geometriya komandy, sozdayushchaya energiyu. Kratkoe rukovodstvo $k$ deystviyu liderov [Model " $5 \mathrm{~F}$ " - Team geometry that creates energy. A quick guide to action for leaders]. Moscow: IP Dolgov Maksim Valeryevich, 2016. 192 p. (In Russian)

Dolgov M.V. Osobennosti upravlencheskikh komand na gosudarstvennoy grazhdanskoy sluzhbe [Features of management teams in public service bodies], Vestnik RUDN. Seriya «Gosudarstvennoe i munitsipalnoye upravleniye» [перевод], 2018, 5 (4), pp. 365-373. (In Russian)

Filonovich S.R. Liderstvo kak integrlnaya problema nauk o povedenii [Leadership as an integral problem of behavioral sciences], Rossiyskiy zhurnal menedzhmenta [Russian Management Journal], 2007, 5, pp. 91-100. (In Russian)

Filonovich S.R. Teorii liderstva v menedzhmente: Istoriya i perspektivy [Leadership Theories in Management: History and Perspectives], Rossiyskiy zhurnal menedzhmenta [Russian Management Journal], 2003, 1, pp. 3-24. (In Russian)

Kornienko V.I. Formirovanie upravlencheskikh komand novogo pokoleniya [Formation of new generation management teams]. Moscow: RAGS, 2000. 150 p. (In Russian)

Lapina N.Yu., Chirikova A.E. Regiony-lidery: economika o politicheskaya dinamika [Leading Regions: Economy and Political Dynamics]. Moscow: IS RAS, 2002. 324 p. (In Russian)

Maslyukova M.V. "Zolotyye pravila" menedzhmenta novoy epokhi ["Golden rules" of management of a new era], Konsultant [Consultant], 2005, 9, pp. 18-25. (In Russian)

Sheburakov I.B. Formirovaniye proyektnykh komand v gosudarstvennykh organakh [Formation of Project Teams in Government Bodies], Upravleniye razvitiyem personala [Personnel development management], 2017, 1, pp. 16-24. (In Russian)

Upravlenie personalom [Personnel Management]. Ed. by T.Yu. Bazarov, B.L. Eremin. $2^{\text {nd }}$ ed. Moscow: Uniti, 2002. 560 p. (In Russian)

Vikhansky O.S. Mirakyan A.G. Novoe tysyacheletiye: upravlencheskiye anomalii i sovremennyye kontseptsii liderstva [New Millennium: Management Anomalies and Modern Concepts of Leadership], Rossiyskiy zhurnal menedzhmenta [Russian Management Journal], 2018, 1, pp. 131-154. (In Russian)

Zhukov Yu.M., Zhuravlev A.V., Pavlova E.N. Tekhnologii komandoobrazovaniya [Team building technologies]. Moscow: Aspekt Press, 2008. 320 p. (In Russian) 